\section{Tropical Journal of Pathology and \\ Microbiology}

2020 Volume 6 Number 6 July-August

\title{
The utility of Fine Needle Aspiration Cytology (FNAC) in the diagnosis of head and neck lesions at tertiary health care level
}

\author{
Rameshbhai Patel D. ${ }^{1 *}$, Nandan Chawla S. ${ }^{2}$ \\ DOI: https://doi.org/10.17511/jopm.2020.i06.04 \\ 1* Dipti Rameshbhai Patel, Assistant Professor, Department of Pathology, American International Institute of Medical Sciences, GBH General \\ and Cancer Hospital, Udaipur, Rajasthan, India. \\ 2 Shiv Nandan Chawla, Professor and Head, Department of Pathology, American International Institute of Medical Sciences, GBH General \\ and Cancer Hospital, Udaipur, Rajasthan, India.
}

Introduction: FNAC is particularly suitable in the head and neck areas due to its easy accessibility of target sites, minimally invasive nature, excellent patient compliance, and helping of avoidance of surgery in conditions like non-neoplastic, inflammatory, and some tumors. Aim: To assess the prevalence of different types of head and neck lesions and to test the utility of Fine Needle Aspiration Cytology (FNAC) in the diagnosis of head and neck lesions. Material and Methods: A retrospective study of 224 FNAC of head and neck swellings performed as an outdoor procedure from Jan 2018 to June 2019 at the American International Institute of Medical Sciences (AIIMS), GBH General and cancer hospital, Udaipur, Rajasthan. Results: Out of 224 cases, major aspirates were from lymph node $123(54.91 \%)$, followed by skin and soft tissue $42(18.75 \%)$, thyroid 40 $(17.85 \%)$, salivary gland $13(5.80 \%)$, and Oral cavity $06(2.67 \%)$. Malignant lesions were higher in lymph node $69(56.09 \%)$ and in oral cavity $05(83.33 \%)$. Metastatic carcinoma $66(53.65 \%)$ and lymphoma $03(2.43 \%)$. Colloid goiter $24(60 \%)$, keratinous cyst $27(64.28 \%)$, and Pleomorphic adenoma $04(30.76 \%)$ were common benign lesions in the thyroid, skin and soft tissue, and salivary gland respectively. Conclusions: FNAC can be effectively used in the diagnosis and planning management of various head and neck swellings because it is safe, relatively painless, rapid, outdoor procedure and can differentiate benign from malignant lesions and gives clues for occult primaries in metastatic malignancy.

Keywords: Fine Needle Aspiration Cytology (FNAC), Head and Neck lesions, Lymph Node, Thyroid

Corresponding Author

Dipti Rameshbhai Patel, Assistant Professor, Department of Pathology, American International Institute of Medical Sciences, GBH General and Cancer Hospital, Udaipur, Rajasthan, India. Email: diptum12386@gmail.com
How to Cite this Article

To Browse

Patel DR, Chawla SN. The utility of Fine Needle Aspiration Cytology (FNAC) in the diagnosis of head and neck lesions at tertiary health care level. Trop J Pathol Microbiol. 2020;6(6):387-394. Available From https://pathology.medresearch.in/index.php/jopm/ar ticle/view/469

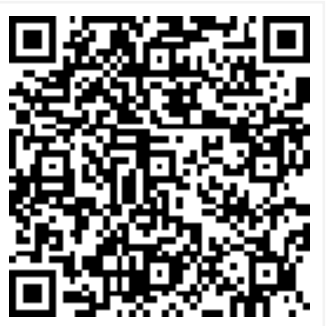

Review Round 2
2020-07-31
$\begin{gathered}\text { Ethical Approval } \\ \text { Yes }\end{gathered}$

Review Round 3

Plagiarism X-checker $6 \%$
Accepted 2020-08-26

C 2020 by Dipti Rameshbhai Patel, Shiv Nandan Chawla and Published by Siddharth Health Research and Social Welfare Society. This is an Open Access article licensed under a Creative Commons Attribution 4.0 International License https://creativecommons.org/licenses/by/4.0/ unported [CC BY 4.0]. 


\section{Introduction}

A great number of diseases of the head and neck region can manifest as a palpable and /or visible lump. These can also be called swellings, growths, tumors, or lumps. Each disease may have a different mode of presentation. For these reasons, diagnosis often becomes difficult in neck swelling. The lesions of the head and neck region comprised several different congenital, inflammatory conditions, and benign or malignant tumors [1]. In palpable head and neck lesions, the most commonly encountered lesion are lymph nodes, thyroid, and major salivary glands along with other rarely encountered lesions like subcutaneous tissue swellings, lumps of skin appendages, and oral cavity lesions [2]. It greatly influences on planned treatment, when these lesions are early diagnosed and differentiated from inflammatory to neoplastic etiology [3].

The Martin and Ellis introduced the first modern technique of FNAC in 1930 for the evaluation of various palpable lumps and now this technique has become a popular procedure due to its easy accessibility of target sites and minimally invasive nature [4]. FNAC is particularly suitable in the head and neck areas due to its easy accessibility of target sites, minimally invasive nature, excellent patient compliance, and helping of avoidance of surgery in certain conditions like non-neoplastic, inflammatory conditions, and some tumors [5]. FNAC has been found to be a safe, relatively painless, rapid, and highly cost-effective technique. Also, It is an accurate, sensitive, and specific method found by some experienced workers [6]. The advantage of FNAC is that it is an outdoor procedure, requires minimal equipment, causes minimal discomfort to the patient, repeatable to obtain adequate material for cytological analysis, and reduces the rate of the exploratory procedure [7].

FNAC does not give the same architectural detail as histology and it also leads to bloody aspirates in highly vascular organs like the thyroid, but it can provide cells from the entire lesion as many passes through the lesion can be made while aspirating [8]. FNAC is considered the gold standard diagnostic test in the evaluation of a thyroid nodule, and other tests like ultrasound and a Nuclear scan should be used in concurrence with FNAC [9]. Diagnosis of salivary gland tumors can be done by FNAC because it can differentiate between a malignant and a benign tumor with over $90 \%$ accuracy [10]. In our
Country, Malignancies in lymph nodes are predominantly metastatic in nature with an incidence varying from 65.7-80.4\% and lymphomas range from $2-15.3 \%$ among lymph nodes aspirated from all sites [11].

Although the histopathological examination is considered to be the gold standard in diagnosis especially in lymphomas, FNAC may be the only tool for diagnosis and further management of the patients in metastatic malignancy as it gives clues for occult primaries [11]. The Prime objective of the present study was to assess the prevalence of different types of head and neck lesions and to test the utility of FNAC in the diagnosis of head and neck lesions. The main outcome from this analysis that Fine needle aspiration cytology is a safe, relatively painless, and rapid technique that can be used in the diagnosis of various head and neck swellings and helps in planning the management of these lesions.

\section{Material and Methods}

Place of the study: Central clinical Laboratory, Department of Pathology, American International Institute of Medical Sciences (AIIMS) and $\mathrm{GBH}$ General and Cancer Hospital, Bedwas, Udaipur, Rajasthan (India).

Ethical considerations and permission: Ethical considerations and permission were met through the Institutional ethical committee.

Duration and type of the study: The present retrospective study was conducted over 1 and $1 / 2$ year period from Jan 2018 to June 2019.

Study subject: Those patients who presented with superficially palpable head and neck lesion in Medicine, Surgical, Dermatology, and Dental OPD or admitted in the hospital and underwent FNAC were considered as the study subject.

Inclusion Criteria: All age groups (1-90 years) of patients of palpable head and neck lesions including oral cavity lesion.

Exclusion Criteria: Patients with inconclusive cytological results and incomplete demographic details were excluded from this study.

Sampling Method: This retrospective study included 224 cases of FNAC done on head and neck swellings performed as outdoor procedure over 1 and $1 / 2$ year period. The history has been taken from all patients related to head and neck swelling, and 
Relevant questions were asked related to the etiological cause along with the present, past, and family history of tuberculosis and history of consumption of tobacco-related products, history of any radiotherapy, or chemotherapy taken in cancer patients. Information from other radiological and laboratory investigations was also noted. Patients were explained about the procedure and its indication. Their written consent was taken. Maximum efforts were been made to reassure the patient as to the safety, simplicity of the procedure, and minimal discomfort.

The area of palpable swelling was cleaned with spirit and then it was fixed with the thumb and index finger of one hand and with all aseptic precautions, a 22-23G needle with $10 \mathrm{ml}$ syringe was inserted into the swelling and negative pressure was applied. Aspiration was done from different directions and depth of the swelling and aspiration material was smeared on the glass slides and immediately fixed in $90 \%$ alcohol for routine hematoxylin and eosin stain and Pap stain and few were air-dried for Giemsa stain.

The Ziehl-Neelsen (ZN) stain for acid-fast bacilli was done in suspected tubercular lesions. The stained slides were mounted by DPX and examined under the light microscope and reported. Fine Needle Aspiration Diagnosis was correlated with Detail of relevant clinical findings and other investigations like USG neck or CT neck and previous any excision biopsy report. Cytological findings were recorded and patients were advised medical treatment and follow up or biopsy and surgical intervention depending upon the pathology.

Statistical Analysis: Data was recorded in MS office 2007 and analyzed according to age and gender, site of pathology, nature of swelling, and cytological diagnosis. Percentages were calculated for estimating the frequency of various cytological conditions diagnosed on FNAC in patients of head and neck swellings.

\section{Results}

A total of 224 patients had undergone FNAC of the head and neck lesion during the study period from Jan 2018 to June 2019.Out of the 224 cases, 133 $(59.37 \%)$ cases were male and $91(40.62 \%)$ cases were female ( $M$ : $F$ ratio- 1.4:1). The age range of the patients in this study was between 1 to 90 years. The highest numbers of cases were recorded in the fifth and sixth decades of life with 47
(20.98\%) cases and $40 \quad(17.85 \%)$ cases respectively. Among the age group of $41-50$ years, $28(59.57 \%)$ cases were male and $19(40.42 \%)$ cases were female noted (Table-1).

Out of 224 cases, the largest number of aspirates were from lymph nodes 123 (54.91\%), followed by skin and soft tissue $42(18.75 \%)$. Thyroid lesions accounted for $40(17.85 \%)$ cases followed by salivary gland lesions $13(5.80 \%)$ cases and oral cavity lesions $6(2.67 \%)$ cases (Table 2 ).

Table -1: Distribution cases according to age and sex.

\begin{tabular}{|l|l|l|l|}
\hline \multicolumn{1}{|c|}{ Age (years) } & Male & \multicolumn{1}{|c|}{ Female } & \multicolumn{1}{|c|}{ Total (\%) } \\
\hline $1-10$ & 07 & 00 & $07(3.12 \%)$ \\
\hline $11-20$ & 11 & 08 & $19(8.48 \%)$ \\
\hline $21-30$ & 20 & 18 & $38(16.96 \%)$ \\
\hline $31-40$ & 17 & 17 & $34(15.17 \%)$ \\
\hline $41-50$ & 28 & 19 & $47(20.98 \%)$ \\
\hline $51-60$ & 25 & 15 & $40(17.85 \%)$ \\
\hline $61-70$ & 15 & 12 & $27(12.05 \%)$ \\
\hline $71-80$ & 09 & 02 & $11(4.91 \%)$ \\
\hline $81-90$ & 01 & 00 & $01(0.44 \%)$ \\
\hline Total & $133(59.37 \%)$ & $91(40.62 \%)$ & $224(100 \%)$ \\
\hline
\end{tabular}

Table-2: Distribution of head and neck swelling according to the site of pathology.

\begin{tabular}{|l|l|l|}
\hline \multicolumn{1}{|c|}{ Site of pathology } & Number & \multicolumn{1}{c|}{ Percentage } \\
\hline Lymph node & 123 & 54.91 \\
\hline Thyroid gland & 40 & 17.85 \\
\hline Salivary gland & 13 & 5.80 \\
\hline Skin and soft tissue & 42 & 18.75 \\
\hline Oral cavity & 06 & 2.67 \\
\hline Total & 224 & \\
\hline
\end{tabular}

Out of 224 cases, 139 (62.05\%) cases were benign and $85(37.94 \%)$ cases were malignant. In lymph node aspirates, the malignant lesion was higher 69 (56.09\%) cases as compared to benign one noted $54(43.90 \%)$ cases. Malignant cases were also high in the oral cavity accounted for $05(83.33 \%)$ and benign $01(16.66 \%)$ case (Table 3$)$.

Table-3: Distribution of benign and malignant head and neck lesions according to the site of FNAC.

\begin{tabular}{|l|l|l|l|}
\hline \multicolumn{1}{|c|}{ Site of FNAC } & No & \multicolumn{1}{c|}{ Benign (\%) } & \multicolumn{1}{c|}{ Malignant (\%) } \\
\hline Lymph node & 123 & $54(43.90 \%)$ & $69(56.09 \%)$ \\
\hline Thyroid gland & 40 & $33(82.5 \%)$ & $07(17.5 \%)$ \\
\hline Salivary gland & 13 & $10(76.92 \%)$ & $03(23.07 \%)$ \\
\hline Skin and soft tissue & 42 & $41(97.61 \%)$ & $01(2.38 \%)$ \\
\hline Oral cavity & 06 & $01(16.66 \%)$ & $05(83.33 \%)$ \\
\hline Total & 224 & $139(62.05 \%)$ & $85(37.94 \%)$ \\
\hline
\end{tabular}


Table-4: Distribution of head and neck lesion according to cytological diagnosis.

\begin{tabular}{|c|c|c|c|c|}
\hline $\begin{array}{c}\text { Site of } \\
\text { pathology }\end{array}$ & Benign lesions & No $(\%)$ & $\begin{array}{l}\text { Malignant } \\
\text { lesions }\end{array}$ & $\begin{array}{l}\text { No } \\
(\%)\end{array}$ \\
\hline \multirow[t]{4}{*}{$\begin{array}{l}\text { Lymph node } \\
\text { (Total-123) }\end{array}$} & Acute suppurative lesion & $\begin{array}{l}07 \\
(5.69 \%)\end{array} \mid$ & Lymphoma & $\begin{array}{l}03 \\
(2.43 \\
\%)\end{array}$ \\
\hline & Reactive lymphadenitis & $\begin{array}{l}24 \\
(19.51 \\
\%)\end{array}$ & $\begin{array}{l}\text { Metastatic } \\
\text { carcinoma }\end{array}$ & $\begin{array}{l}66 \\
(53.6 \\
5 \%)\end{array}$ \\
\hline & $\begin{array}{l}\text { Granulomatous } \\
\text { lymphadenitis }\end{array}$ & $\begin{array}{l}13 \\
(10.56 \\
\%)\end{array}$ & $\begin{array}{l}\text { a-Metastatic } \\
\text { squamous cell } \\
\text { carcinoma }\end{array}$ & $\left(\begin{array}{l}54 \\
(43.9 \\
0 \%)\end{array}\right.$ \\
\hline & Tuberculous lymphadenitis & $\begin{array}{l}10 \\
(8.13 \%)\end{array}$ & 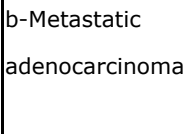 & $\begin{array}{l}12 \\
(9.75 \\
\%)\end{array}$ \\
\hline \multirow[t]{4}{*}{$\begin{array}{l}\text { Thyroid gland } \\
\text { (Total-40) }\end{array}$} & Thyroglossal cyst & $\begin{array}{l}05 \\
(12.5 \%)\end{array}$ & $\begin{array}{l}\text { Papillary thyroid } \\
\text { carcinoma }\end{array}$ & $\begin{array}{l}04 \\
(10 \%\end{array}$ \\
\hline & Colloid Goiter & $\begin{array}{l}24 \\
(60 \%)\end{array}$ & $\begin{array}{l}\text { Medullary } \\
\text { carcinoma }\end{array}$ & $\mid \begin{array}{l}02 \\
(5 \%)\end{array}$ \\
\hline & Grave's disease & $\begin{array}{l}01 \\
(2.5 \%)\end{array}$ & $\begin{array}{l}\text { Follicular } \\
\text { carcinoma }\end{array}$ & $\begin{array}{l}01 \\
(2.5\end{array}$ \\
\hline & Hashimoto thyroiditis & $\begin{array}{l}03 \\
(7.5 \%)\end{array}$ & & $\%)$ \\
\hline \multirow[t]{4}{*}{\begin{tabular}{|l|} 
Salivary \\
gland (Total- \\
$13)$
\end{tabular}} & Sialadenitis & $\begin{array}{l}03 \\
(23.07 \\
\%)\end{array}$ & $\begin{array}{l}\text { Mucoepidermoid } \\
\text { carcinoma }\end{array}$ & $\begin{array}{l}02 \\
(15.3 \\
8 \%)\end{array}$ \\
\hline & Sialadenosis & $\begin{array}{l}01 \\
(7.69 \%)\end{array}$ & & \\
\hline & Warthin tumor & $\begin{array}{l}02 \\
(15.38 \\
\%)\end{array}$ & $\begin{array}{l}\text { Adenoid cystic } \\
\text { carcinoma }\end{array}$ & $\begin{array}{l}01 \\
(7.69 \\
\%)\end{array}$ \\
\hline & Pleomorphic adenoma & $\begin{array}{l}04 \\
(30.76 \\
\%)\end{array}$ & & \\
\hline \multirow{6}{*}{$\mid \begin{array}{l}\text { Skin and soft } \\
\text { tissue (Total- } \\
42)\end{array}$} & Non-neoplastic cyst & $\begin{array}{l}02 \\
(4.76 \%)\end{array} \mid$ & $\begin{array}{l}\text { Basal cell } \\
\text { carcinoma }\end{array}$ & $\begin{array}{l}01 \\
(2.38\end{array}$ \\
\hline & Keratinous cyst & $\begin{array}{l}27 \\
(64.28 \\
\%)\end{array}$ & & $\%)$ \\
\hline & $\begin{array}{l}\text { Acute suppurative } \\
\text { Inflammation }\end{array}$ & & & \\
\hline & (abscess) & $\begin{array}{l}02 \\
(4.76 \%)\end{array}$ & & \\
\hline & $\begin{array}{l}\text { Granulomatous } \\
\text { inflammation associated } \\
\text { with actinomycosis }\end{array}$ & $\begin{array}{l}01 \\
(2.38 \%)\end{array} \mid$ & & \\
\hline & Lipoma & $\begin{array}{l}09 \\
(21.42 \\
\%)\end{array}$ & & \\
\hline
\end{tabular}

\begin{tabular}{|l|l|l|l|l|}
\hline Oral cavity & Retention & 01 & Squamous cell & 04 \\
$($ Total-6) & cyst & $(16.66 \%)$ & carcinoma & $(66.66 \%)$ \\
\cline { 4 - 5 } & & & $\begin{array}{l}\text { Mucoepidermoid } \\
\text { carcinoma }\end{array}$ & 01 \\
& & & $(16.66 \%)$ \\
\hline
\end{tabular}

Out of 123 lymph node aspirates, malignant lesions were $69(56.09 \%)$ cases and benign lesions were 54 $(43.90 \%)$ cases (Table-3). Incidence of malignant lesions was higher in lymph node as compared to benign one (Table-3). In malignant lesions of lymph node aspirates, $03(2.43 \%)$ cases were lymphoma and $66(53.65 \%)$ cases were metastatic malignancy noted. Metastatic squamous cell carcinoma was in $54(43.90 \%)$ cases and metastatic adenocarcinoma was in $12(9.75 \%)$ cases. In benign lesions, reactive lymphadenitis was the most common cytological findings in $24(19.51 \%)$ cases followed by Granulomatous lymphadenitis in $13(10.56 \%)$ cases and tuberculous lymphadenitis in 10 (8.13\%) cases. Acute suppurative lesion accounted for 07 (5.69\%) cases (Table 4).

Out of 40 thyroid aspirates, $33(82.5 \%)$ cases were benign and $07(17.5 \%)$ cases were malignant (Table-3). Colloid goiter was the most common cytological diagnosis in $24(60 \%)$ cases. Thyroglossal cyst accounted for 05(12.5\%) cases, Hashimoto thyroiditis in $03(7.5 \%)$ cases, and Grave's disease in $01(2.5 \%)$ cases. In malignant cases, papillary thyroid carcinoma accounted for 04 $(10 \%)$ cases followed by medullary carcinoma in 02 (5\%) cases and Follicular carcinoma in 01 (2.5\%) cases (Table 4).

Out of 13 cases of the salivary gland, $03(23.07 \%)$ cases were of Sialadenitis, $01(7.69 \%)$ was of Sialadenosis and $02(15.38 \%)$ cases were of Warthin tumor. Pleomorphic adenoma was the most common lesion in $04(30.76 \%)$ cases. In malignant cases, Mucoepidermoid Carcinoma accounted for 02 $(15.38 \%)$ cases followed by Adenoid cystic Carcinoma in $01(7.69 \%)$ cases (Table 4$)$.

Out of 42 skin and soft tissue lesions, benign were $41(97.61 \%)$ cases and malignant was $01(2.38 \%)$ case (Table-3). Keratinous cyst and infected Epidermal Inclusion cyst was the most common lesion in $27(64.28 \%)$ cases followed by lipoma in $09(21.42 \%)$ cases. Non neoplastic cyst was 02 $(4.76 \%)$ cases, Acute suppurative Inflammation (abscess) was $02(4.76 \%)$ cases. $01(2.38 \%)$ case was of Granulomatous inflammation Associated with actinomycosis noted. 01 (2.38\%) case was of Basal cell carcinoma (Table 4).

Out of 6 oral cavity lesions, $01(16.66 \%)$ case was 
Benign and $05(83.33 \%)$ were malignant lesions (Table-3).In malignant lesions, $04(66.66 \%)$ were Squamous cell Carcinoma and $01(16.66 \%)$ case was Mucoepidermoid carcinoma noted. In benign lesions, $01(16.66 \%)$ case was the Retention cyst found (Table 4).

\section{Discussion}

The present study was undertaken to assess the incidence and nature of various head and neck swellings by FNAC.FNAC results from 224 patients with head and neck masses were reviewed and analyzed. The results were analyzed according to age, gender, site of pathology, nature of swelling, and cytological diagnosis.

In the present study, the peak age group was 5 the decades (41-50 years) constituting $20.98 \%$ of all patients of head and neck lesions. The Study conducted by Solanki Piyush K et al [12] observed that head and neck lesions were relatively common in the second decades and fifth decades constituting $22 \%$ and $22 \%$ respectively out of 100 cases.

In the present study, $133(59.37 \%)$ cases were male and $91(40.62 \%)$ were female and the male to female ratio was $1.4: 1$. In the study of Jandu and Webster et al [13] $\mathrm{M}$ : the $\mathrm{F}$ ratio was 1.3:1 and in the study of Cheng and Dorman [14], it was 1.5:1 which are comparable to the present study.

In the present study, the largest numbers of aspirates were from lymph nodes $54.91 \%$, followed by Skin and soft tissue $18.75 \%$, thyroid $17.85 \%$, and salivary gland $5.80 \%$ and oral cavity $2.67 \%$ noted.

The study of Shaan Khetrapal et al [15] noted that the largest number of cases from lymph node lesions $64.1 \%$ and the least number of cases were from oral cavity $1.03 \%$ which is comparable to the present study.

Table-5: Comparison of the site-wise distribution of head and neck lesions between the present study and other studies.

\begin{tabular}{|l|l|l|l|l|}
\hline \multicolumn{1}{|c|}{ Studies } & \multicolumn{1}{|c|}{$\begin{array}{c}\text { Lymph } \\
\text { nodes } \%\end{array}$} & \multicolumn{1}{|c|}{$\begin{array}{c}\text { Skin and Soft } \\
\text { tissue } \%\end{array}$} & $\begin{array}{c}\text { Thyroid } \\
\%\end{array}$ & $\begin{array}{c}\text { Salivary } \\
\text { gland } \%\end{array}$ \\
\hline Present study & $54.91 \%$ & $18.75 \%$ & $17.85 \%$ & $5.80 \%$ \\
\hline Amit M et al [7] & $56.37 \%$ & $19.2 \%$ & $10.90 \%$ & $11.44 \%$ \\
\hline $\begin{array}{l}\text { Goswami R et al } \\
{[16]}\end{array}$ & $53.8 \%$ & $22.1 \%$ & $16.9 \%$ & $7.1 \%$ \\
\hline $\begin{array}{l}\text { Modi P et al } \\
{[17]}\end{array}$ & $64.9 \%$ & $12.1 \%$ & $16.1 \%$ & $6.8 \%$ \\
\hline
\end{tabular}

Table-5 $[7,16,17]$ shows the comparison of the present study with other studies on the basis of the distribution of head and neck lesions. It is noted that maximum aspirates are from lymph nodes in head and neck lesions, followed by Skin and Soft tissue, thyroid, and salivary gland lesions. In the present study, $62.05 \%$ cases were benign and $37.94 \%$ cases were malignant, which is comparable to the study of Tobih JE et al [18] who observed benign lesions $59.0 \%$ and malignant lesions $41.0 \%$.

FNAC is a simple, safe, painless, rapid, and costeffective technique that can be performed as an outdoor procedure to diagnose and to differentiate various benign and malignant lesions. In the present study, Among 123 lymph node lesions, $56.09 \%$ were malignant lesions and $43.90 \%$ were benign lesions. This is correlated with the study of Pramod Chandra pathy et al [19] who found $51.27 \%$ malignant and $48.27 \%$ benign. Similar findings were also noted in the study of Steel et al [20] in which $59 \%$ were malignant and $34 \%$ were benign. In the present study, metastatic carcinoma was most common in $53.65 \%$ cases followed by primary lymphoma in $2.43 \%$ cases and metastatic squamous cell carcinoma was the most common metastatic malignancy in $43.90 \%$ followed by metastatic adenocarcinoma in $9.75 \%$ which is correlated with the study of Pramod Chandra Pathy et al [19] who reported metastatic lesions $88.1 \%$ and primary lymphoma $11.98 \%$ and metastatic squamous cell carcinoma $50.77 \%$ and metastatic adenocarcinoma $18.87 \%$. In the present study, reactive lymphadenitis was most common in benign lesions $19.51 \%$ followed by granulomatous lymphadenitis $10.56 \%$ and Tubercular lymphadenitis $8.13 \%$ which is similar to the study of Jadhav DS et al [21] noted $32.62 \%, 24.03 \%$, and $14.16 \%$ of cases respectively. Similar findings were also reported by Ajay Singh Thakur et al [22] with $30.04 \%$ reactive lymphadenitis and $17.96 \%$ granulomatous lymphadenitis and $11.44 \%$ Tubercular lymphadenitis.

In the present study, the cytological smear of metastatic squamous cell carcinoma was richly cellular and showed tight cohesive clusters of malignant squamous epithelial cells which were highly pleomorphic with high $\mathrm{N}: \mathrm{C}$ ratio, hyperchromatic nuclei, and prominent nucleoli. The background showed necrotic debris, keratinous material, and lymphoglandular bodies. The cytological smear of metastatic adenocarcinoma showed a glandular pattern of arrangement of cells 
With a round hyperchromatic nucleus and a moderate amount of vacuolated cytoplasm. The present study observed that Few cases of the metastatic squamous cell carcinoma were arising from upper aerodigestive tract cancer and few cases were recurrence cases noted in operated cancer patients of oral cavity region. FNAC not only confirms the presence of metastatic malignancy but also gives clues for primary malignancy so it takes considerable value in assessing disease staging and documentation of recurrence.

FNAC helps as a guide to the appropriate therapeutic management to either locally excise a benign tumor or plan radical surgery or other alternative treatment modalities in case of malignancy. In the present study, among thyroid lesions, Colloid Goiter was the commonest benign lesion comprising $60 \%$ which is correlated with the study of Rashmi Rekha Goswami et al [16] found $67.3 \%$ and the study of Dr. Kusum Borsaikia [23] found $62.50 \%$ and study of Apoorva KP et al [24] found $64.5 \%$. In the present study, Papillary carcinoma was highest $10 \%$ in a malignant lesion which is similar to the study of Rashmi Rekha Goswami et al [16] noted $5.4 \%$ and the study of Chauhan Savitri et al [25] noted 3.1\%.

In the present study, out of total skin and soft tissue lesions, Keratinous cyst most common 64.28\% followed by lipoma $21.42 \%$ which is similar to the findings of Kishor et al [26] where the epidermal cyst was $57.14 \%$ and lipoma was $23.8 \%$. A similar study of Rashmi Rekha Goswami et al [16] where epidermal cyst $40.6 \%$ and lipoma $23.9 \%$.

This technique requires minimal equipment and no anesthesia, causes minimal discomfort to the patient and it has high diagnostic accuracy in salivary gland lesions. In the present study, in salivary gland lesions, Pleomorphic adenoma was the most common benign lesion noted $30.76 \%$ and Mucoepidermoid carcinoma $15.38 \%$ noted in the present study which is comparable to various studies of Solanki Piyush $\mathrm{K}$ et al [12] noted $30 \%$ and $10 \%$ respectively and Rashmi Rekha Goswami et al [16] noted $43.5 \%$ and $11.3 \%$ respectively. In oral cavity lesions, Squamous cell Carcinoma was a common malignant lesion seen in 04(66.66\%) cases. Few cases of it involved buccal mucosa and few involved tongues. $01(16.66 \%)$ case of Mucoepidermoid carcinoma involved hard palate. The study of Sakarwal et al reported that Squamous cell Carcinoma was the most common malignant lesion in the oral cavity accounted $79.31 \%$ [27].

\section{Limitations}

01 . The present study is hospital-based and not community-based therefore the prevalence of diseases may vary due to patient selection bias.

02. False-positive diagnoses can be resulted by regenerative epithelial hyperplasia and squamous metaplasia in sialadenitis.

03. False-negative diagnoses can occur due to faulty technique, Central cystic, hemorrhage, or necrotic area which are devoid of diagnostic cells, Small foci of neoplastic lesion nearby reactive non-neoplastic mass, highly fibrotic lesion, and interpretative error. False-negative diagnosis is most commonly seen in mucoepidermoid carcinoma because cystic fluid dilutes the tumor cells or because the bland looking tumor intermediate cells are misinterpreted as benign cells.

04. Typing of reactive lymphadenitis can't be done by FNAC.

05. Definitive diagnosis is not always possible which requires histopathological confirmation in certain conditions like lymphoma.

\section{Conclusion}

The present study concluded that a wide range of diseases of the head and neck region can be manifested as swelling/lump or mass and they can be diagnosed by fine-needle aspiration cytology. The present study found that reactive lymphadenitis, keratinous cyst, and colloid goiter are a common cause of head and neck swellings. The current study also indicates that metastatic carcinomas are important and common causes of cervical lymphadenopathy compared to reactive lymphadenitis. Mainly Metastatic squamous cell carcinoma attend the major malignant lesion in this tertiary care center may be due to increased incidence of squamous cell carcinoma of an upper aero-digestive tract in this region. The study also concluded that FNAC not only confirms the presence of metastatic malignancy but also provides clues for primary malignancy so it helps in assessing disease staging.

At last, the present study confirms that FNAC can be effectively used in the diagnosis and planning management of various head and neck swellings because it is safe, relatively painless, rapid, outdoor procedure and can differentiate benign from malignant lesions, gives clues for occult primaries in 
Metastatic malignancy and avoids unnecessary surgeries. Thus, FNAC can be recommended as the best initial work up in the diagnosis and management of head and neck swellings.

\section{What does the study add to the existing knowledge}

This study provides the knowledge that despite certain limitations of FNAC, It can be used as an effective tool to differentiate benign lesions from malignant lesions as well as to confirm metastatic malignancy thereby it will become helpful to clinicians, surgeons, and on-surgeons for planning treatment modalities and assessing disease staging.

\section{Author's Contribution}

Dr. Dipti R Patel: Literature search and review, collected all data, performed data analysis, and prepared the manuscript.

Dr. Shiv Nandan Chawla: Guided in the discussion and conclusion part and edited the article.

\section{Reference}

01. Mc Guirt WF. Differential diagnosis of neck masses, In- Cummings CW, Flint PW, Harkar LA (eds), Cummings Otolaryngology Head and Neck Surgery. 4th ed, Mosby- Elsevier. 2005. p. 2542 [Crossref]

02. Chauhan S, Rathod D, Joshi DS. FNAC of swellings of head and neck region. Indian J App Basic Med Sci. 2011;13(17)1-6.

Available at: [Article] [Crossref]

03. Rathod GB, Parmar P. Fine needle aspiration cytology of swellings of head and neck region. Indian J Med Sci. 2012;66(3-4)49-54.

doi: 10.4103/ 0019-5359.110896 [Crossref]

04. Martin $H$, Ellis EB. Biopsy of needle puncture and aspiration. Ann Surg. 1930;92(2)169-181. doi: 10.1097/00000658-193008000-00002 [Crossref]

05. Abrari A, Ahmad SS, Bakshi V. Cytology in the otorhinolaryngologist's domain - a study of 150 cases, emphasizing diagnostic utility and pitfalls. Indian J Otolaryngol Head Neck Surg. 2002;54(2)107-110.

doi: 10.1007/ BF 02968727 [Crossref]
06. Orell SR Sterrett GF, Walters MN, WhitakerD. Introduction- Manual and Atlas of fine needle Aspiration Cytology. 2nd ed, Churchill livingstone Edinburg. 1992;44-59.

[Crossref]

07. Maniyar AU, Patel HL, Parmar BH. Study of Cytodiagnosis of Head and Neck Neoplastic Lesions and Comparision with Histopathology. Res Rev- J Med Health Sci. 2013;2(2)54-59. Available at [Article] [Crossref]

08. Kirk RM, Ribbans WJ. Clinical Surgery in General. 4th ed, Edinburgh- Elsevier. 2004. [Crossref]

09. Nguyen GK, Lee MW, Ginsberg J, Wragg T, Bilodeau D. Fine Needle Aspiration of the Thyroid- an overview. Cyto J. 2005;2(12)17421764.

doi: $10.1186 / 1742-6413-2-12$ [Crossref]

10. Burnand KG, Young $A E$, Lucas J, Rrolands $B J$, Scholefield J. The new Aird's companion in surgical studies. 3rd ed, Elsevier, Churchill Livings tone. 2005.

[Crossref]

11. Wilkinson AR, Mahore SD, Maimoon SA. FNAC in the diagnosis of lymph node malignancies- $A$ simple and sensitive tool. Indian J Med Paediatr Oncol. 2012;33(1)21. doi:10.4103/0971-5851.96964 [Crossref]

12. Solanki PK, Patel AP, Taviad PP, Chaudhari VP, Patel SM. Fine needle aspiration cytology as a diagnostic procedure in head and neck swellings. Nat J Comm Med. 2012;3(3)433-436. [Crossref]

13. Pathy PC, Hota SK, Dash S, Samantaray $S$, Panda $S$, Rout N. Analysis of FNAC in diagnosis of lymphadenopathy-a retrospective study from a regional cancer centre, Cuttack, Odisha. Int J Res Med Sci. 2017;5(12)5287-5292. doi: $10.18203 / 2320-6012 . i j r m s 20175442$ [Crossref]

14. Thakur AS, Gahine R, Kulkarni V. Evaluation of fine needle aspiration cytology in the diagnosis of head and neck masses and its correlation with histopathological findings. Int J Adv Med. 2016;3(3)699-707.

doi: $10.18203 / 2349-3933 . i j a m 20162521$ [Crossref] 
15. Jandu $M$, Webster $K$. The role of operator experience in fine needle aspiration cytology of head and neck masses. Int J Oral Maxillofac Surg. 1999;28(6)441-444.

doi: $10.1016 /$ S0901-5027(99)80057-5 [Crossref]

16. Khetrapal S, Jetley S, Jairajpuri Z, Rana S, Kohli $S$. fnac of head and neck lesions and its utility in clinical diagnosis- a study of 290 cases. Nat J Med Res. 2015;5(1)33-38.

[Crossref]

17. Goswami RR, Baruah D, Devi G. FNAC spectrum of Head and neck lesions-A Retrospective Study. J Evid Based Med Healthcare. 2016;3(13)400405.

doi: $10.18410 / j e b m h / 2016 / 94$ [Crossref]

18. Modi P, Oza H, Bhalodia J. Utility and adequacy of fine needle aspiration cytology in head and neck lesions- A hospital-based study. Int J Sci Study. 2014;2(8)100-105.

[Crossref]

19. Adedeji TO, Tobih JE, Olaofe O, Akinyemi HA and Sogebi OA. Fine Needle Aspiration and Cytology in the Management of Head and Neck Masses in Osogbo, South Western Nigeria. Otolaryngol Open Access J. 2018;3(1)1-7. doi: 10.23880/ooaj-16000165 [Crossref]

20. Sakarwal N, Awasthi S, Dutta S, Nizammudin S, Kumar A, Ahmad $F$, et al. Fine needle aspiration cytology- A diagnostic tool for oral lesions. Int J Sci Stud. 2015;3(2)90-94.

doi: $10.17354 /$ ijss/2015/220 [Crossref]

21. Suryawanshi KH, Damle RP, Dravid NV, Tayde $Y$. Spectrum of FNAC in palpable head and neck lesions in a tertiary care hospital in India-a 3 years study. Indian J Pathol Oncol. 2015;2(1)713.

[Crossref]
22. Cheng AT, Dorman B. Fine needle aspiration cytology- the Auckland experience. Aust N Z J Surg. 1992;62(5)368-372.

doi: 10.1111/j.1445-2197.1992.tb07205.x [Crossref]

23. Steel BL, Schwartz MR, Ibrahim R. Fine needle aspiration biopsy in the diagnosis of lymphadenopathy in 1103 patients Role, limitations and analysis of diagnostic pitfalls. Acta Cytol. 1995;39(1)76-81.

[Crossref]

24. Jadhav DS, Barge AK, Valand AG. Study of fine needle aspiration cytology of palpable head and neck lesions in tertiary care centre. Indian J Pathol Oncol. 2018;5(3)375-381.

doi: $10.18231 / 2394-6792.2018 .0073 \quad$ [Crossref]

25. Borsaikia K, Patar M. A Study of palpable head and neck swellings by FNAC - a hospital based analysis in a tertiary referral centre. Int $\mathrm{J}$ Sci Res. $2018 ; 7(4) 72-74$.

doi: $10.36106 /$ ijsr [Crossref]

26. Pandey AK, Bhardwaj A, Maithani T, Kishore S, Singh VP. Distributive Analysis of Head and Neck Swellings with their Cytopathological Correlation. Otorhinolaryngol Clin Int $\mathrm{J}$. 2016;8(3)89-96.

doi: $\quad 10.5005 /$ jp-journals-10003-1239 [Crossref]

27. Chauhan S, Darad D, Dholakia A. Fine needle aspiration cytology of neck lesion-an experience at tertiary care hospital in central Gujarat. Nat J Med Res. 2012;2(3)255-259.

[Crossref] 